\title{
The influence of demographic variables on financial record-keeping in small- and medium-sized enterprises in the South African informal sector
}

\begin{tabular}{|c|c|}
\hline $\begin{array}{l}\text { Authors: } \\
\text { Petronella Jon } \\
\text { Lilian Nwosu² }\end{array}$ & $\begin{array}{l}\mathrm{ck}^{1} \text { (D) } \\
\text { (D) }\end{array}$ \\
\hline $\begin{array}{l}\text { Affiliations: } \\
{ }^{1} \text { Department } \\
\text { Innovative Foc } \\
\text { Faculty of Eco } \\
\text { Management } \\
\text { North-West U } \\
\text { Mahikeng, So }\end{array}$ & $\begin{array}{l}\text { flobal } \\
\text { ussed Talents, } \\
\text { nomics and } \\
\text { Sciences, } \\
\text { niversity, } \\
\text { uth Africa }\end{array}$ \\
\hline $\begin{array}{l}{ }^{2} \text { Department } \\
\text { Faculty of Ecor } \\
\text { Management } \\
\text { North-West U } \\
\text { Mahikeng, Sou }\end{array}$ & $\begin{array}{l}\text { f Accounting, } \\
\text { nomics and } \\
\text { Sciences, } \\
\text { niversity, } \\
\text { th Africa }\end{array}$ \\
\hline $\begin{array}{l}\text { Correspondin } \\
\text { Petronella Jon } \\
\text { petronellajonc }\end{array}$ & $\begin{array}{l}\text { g author: } \\
\text { ck, } \\
\text { k@hotmail.com }\end{array}$ \\
\hline $\begin{array}{l}\text { Dates: } \\
\text { Received: } 041 \\
\text { Accepted: } 04 \\
\text { Published: } 12\end{array}$ & $\begin{array}{l}\text { May } 2021 \\
\text { Jct. } 2021 \\
\text { Jan. } 2022\end{array}$ \\
\hline $\begin{array}{l}\text { How to cite th } \\
\text { Jonck, P. \& Nw } \\
\text { 'The influence } \\
\text { demographic } \\
\text { financial recor } \\
\text { small- and me } \\
\text { enterprises in } \\
\text { African inform } \\
\text { Journal of Eco } \\
\text { Financial Scier } \\
\text { a681. https:// } \\
10.4102 / \text { jef.v1 }\end{array}$ & $\begin{array}{l}\text { is article: } \\
\text { osu, L., 2022, } \\
\text { of } \\
\text { variables on } \\
\text { d-keeping in } \\
\text { dium-sized } \\
\text { the South } \\
\text { al sector', } \\
\text { nomic and } \\
\text { ces 15(1), } \\
\text { doi.org/ } \\
5 \text { i1.681 }\end{array}$ \\
\hline $\begin{array}{l}\text { Copyright: } \\
\text { (C) 2022. The A } \\
\text { Licensee: AOS } \\
\text { is licensed und } \\
\text { Creative Comn } \\
\text { Attribution Lic }\end{array}$ & $\begin{array}{l}\text { uthors. } \\
\text { IS. This work } \\
\text { ler the } \\
\text { nons } \\
\text { ense. }\end{array}$ \\
\hline Read online: & \\
\hline 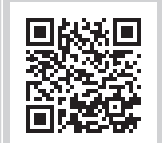 & $\begin{array}{l}\text { Scan this QR } \\
\text { code with your } \\
\text { smart phone or } \\
\text { mobile device } \\
\text { to read online. }\end{array}$ \\
\hline
\end{tabular}

Orientation: Financial record-keeping is a pivotal management tool to analyse profitability, solvency and liquidity, and contribute towards financial efficiency and organisational performance.

Research purpose: The purpose of the research is to explore financial record-keeping practices by small- and medium-sized entities in the informal sector with specific reference to selected demographic variables.

Motivation for study: The contribution of the informal sector to economic growth has recently gained momentum. Financial record-keeping has been identified as keystone to the success of small- and medium-sized entities.

Research approach, design and method: Quantitative data obtained from the national Survey of Employers and the Self-Employed (2017) acquired from Statistics South Africa were utilised, yielding a final sample of 1658 respondents.

Main findings: By means of binary logistic regression, the research established that various demographic variables influence financial record-keeping practices in the informal sector in a statistically significant way. Moreover, it was found that the majority of small- and mediumsized entities do not practise financial record-keeping.

Practical/managerial implications: Interventions should underscore addressing the perceived absence of financial record-keeping practices in the informal sector. Whilst the National Development Plan (NDP) extrapolate the informal sector contributing to job creation by 2030, the effect of these demographic variables on financial record-keeping practices should be taken into cognisance.

Contribution/value-add: The evidence generated by the research presented could be utilised when debating developing or expanding the informal sector. The theoretical contribution relates to modernisation, structure and dependency of the informal sector specifically contributing to the development of a theoretical framework underscoring the influence of demographic variables.

Keywords: financial record-keeping; informal sector; small- and medium-sized entities; secondary research; demographic variables.

\section{Introduction}

Small- and medium-sized enterprises (SMEs) have been known as a fundamental part of every nation's economic activity (Muriithi 2017). Nketsiah (2018) opines that the role of SMEs in economic development cannot be overstated. As such, SMEs could be considered as the backbone of a country's economy (Karagiorgos et al. 2020) and play a crucial role in nation building. Mohamed, Yasseen and Nkhi (2020) noted that the role of SMEs within the South African context remains at the forefront of policy discussions, especially because SMEs contribute to accelerated socio-economic expansion, such as poverty alleviation. Small- and medium-sized enterprises account for a vast portion of new employment opportunities, stimulate growth, create social cohesion, generate income and are known as a primary driver for gross domestic product (GDP) growth (Nketsiah 2018). Muriithi (2017) noted that in African countries, SMEs account for approximately $90 \%$ of commerce in both leading and developing countries contributing to job creation, employment, tax provision and GDP. Similarly, Owolabi, Ogundajo and Olayinka (2016) confirm that SMEs serve as a principal means for poverty alleviation, employment creation and economic development. Muhammad and Isah (2018), citing Fred (2003), noted that SMEs 
contribute to significantly improved living conditions in addition to bringing about substantial local capital formation and high levels of productivity. Nevertheless, SMEs continue to struggle with basic financial record-keeping (Oduro et al. 2014). Hussein and Kühl (2014) noted that inadequate financial record-keeping constitutes a major stumbling block in the growth and survival of SMEs, which might result in economic failure.

Financial recording has been recognised as a topic of interest in academic literature (Myeko \& Madikane 2019; Nketsiah 2018; Williams \& Schaefer 2013). Financial record-keeping can be defined as the documenting of all financial transactions in a systematic and logical manner over a period of time (Muchira 2012). However, many South African business owners neglect this part and parcel of business operations (Myeko \& Madikane 2019). Chelimo and Sopia (2014) indicated that a well-prepared financial record-keeping system will provide the required information to assist business owners to make sound strategic decisions. Financial record-keeping can be used for funding, legal requirements and tax purposes (Chelimo \& Sopia 2014; Myeko \& Madikane 2019). It remains a concern that many SMEs are operating at a deficit without knowing, because of inadequate or the absence of financial record-keeping. Additionally, several SMEs cannot access funding opportunities because of the lack of financial records (Williams \& Schaefer 2013).

Demographic variables have been identified that influence financial record-keeping part and parcel of financial performance (Momanya \& Munene 2013). Vallabh and Mhlanga (2015) expounded that the high failure rate of SMEs necessitates investigating whether demographic variables, for example, gender and education impact business performance. Previously mentioned authors found that demographic variables, such as age, gender, education, income and experience had a considerable impact on business performance of small to medium tourism enterprises in the Eastern Cape. Nyathi and Benedict (2017) revealed that there were more female-owned SMEs in Cape Town than male-owned SMEs. Many scholars from African countries confirm that females are mostly involved in sole-proprietorship SMEs in comparison to their male counterparts (Musah 2017). Furthermore, gender has been identified as a demographic variable influencing SMEs in the Nigerian informal sector (Jayeolo et al. 2020). Musah (2017) indicated that, in Ghana, the age of SME owners predominantly ranged between 35 and 44 years of age. Dawuda and Azeko (2015) showed that the majority of retail clothing industries in South Africa are owned by diploma holders. Momanyi and Munene (2013) identified education as a factor influencing financial record-keeping in Kenya. Whilst, Pretorius (2015) reported that demographic variables significantly influence business compliance with reference to taxation.

In light of the above, the contention of the current research centred on the inability of SMEs to keep financial records ascribed to some demographic variables which might theoretically influence business performance. Various researches have been conducted on the benefits and challenges of bookkeeping and accounting practices of SMEs, impact of financial record-keeping in the growth and survival of SMEs, gender and the performance of informal sector enterprises as well as symptoms of accounting practices that contribute to small business failures (Jayeolo et al. 2020; Muhammad \& Isah 2018; Musah 2017; Sibanda \& Manda 2016). However, there is a paucity of empirical evidence on the influence of demographic variables on financial recordkeeping practices of SMEs in the South African informal sector. Consequently, the primary objective of this research was to investigate the influence of selected demographic variables on financial record-keeping within the South African context.

The significance and relevance of the research reported on could be found in the contribution thereof to the body of knowledge relating to success factors or the alternative contribution to the performance of SMEs in the informal sector against the background of the fundamental role of SMEs in financial growth within the South African context. Hence, the study adopted the modernisation perspective proposed by Huang, Xue and Wang (2020) which emphasised the pivotal role of the informal sector in the economy and the need to develop a better understanding from diverse research on the complexity of SMEs in an informal economy. Three main tenets of the modernisation theory subsume (1) the informal sector will decrease with advanced stages of economic development; (2) expansion of the informal sector is a result of the inability of the formal sector to create sufficient jobs; (3) increases in the rural-to-urban migration ratio leads to informal sector expansion (Huang et al. 2020). Based on this, the article aims to engage with the burgeoning literature drawing attention to the first supposition, namely informal sector development. As such within the South African context, development of the informal sector has been a policy imperative; however, internal barriers such as financial constraints hamper SME growth (Tshuma \& Jari 2013). Rothernberg, Gaduh and Burger (2016) established that the informal sector is experiencing economic instability relating to the ability to keep financial records. This has also prompted the current study to investigate specifically whether some demographic variables influence financial record-keeping of SMEs in the informal sector.

\section{Research purpose and objectives}

Inadequate financial record-keeping has been recognised as a major challenge for many SMEs (Hussein \& Kühl 2014; Oduro et al. 2014). The Global Entrepreneurship Monitoring Report (GEM 2019) showed that South Africa in comparison with other African countries, such as Ghana and Zambia, based on the ability to establish, sustain and develop prosperous new business ventures lags behind. It has been estimated that the failure rate of SMEs is between $70 \%$ and $80 \%$ (Brink, Cant \& Ligthelm 2003). The obstacles facing SMEs include environmental, financial or managerial dynamics (Brink et al. 2003). Financial record-keeping falls under the ambit of 
managerial dynamics and is indicative of management competency (Steyn \& Van Staden 2018). Many scholars reported that well-functioning financial record-keeping influences the quality of decision-making processes in the organisation (see, e.g. Barbara 2010; Boame, Solace \& Issaka 2014; Musah 2017) and can be utilised for legal requirements, tax purposes, funding (Dawuda \& Azeko 2015) as well as accessing credit from financial institutions. Anokyewaa (2015) reported that inadequate financial record-keeping is one of the predominant obstacles that could result in the failure of SMEs. Nketsiah (2018) concurs that one way of promoting SMEs could be to address financial record-keeping capacity. Whilst, Momanyi and Munene (2013) hypothesised that demographic variables influence the financial performance of SMEs and that financial record-keeping is an aspect relating to financial performance. However, it remains unclear how some demographic variables might influence financial recordkeeping of SMEs. The research is premised on the assumption that financial record-keeping is not outsourced because the sample consists of informal sector micro-enterprises with an annual turnover of less than R200 000.00 and not registered for Value Added Tax.

Radipere and Dhliwayo (2014) opine that demographic research is a contentious topic because some question the value thereof, whilst others perceive the same as predictors of business outcome. Specifically, in terms of demographic variables, Van Heerden (2011) reported that South African informal SME owners are in possession of a tertiary qualification and are predominantly female. Shava and Rungani (2016) confirmed that male- and female-owned SMEs perform at similar levels. However, it is asserted that gender might influence financial record-keeping practices of SMEs. In addition, Fatoki and Asah (2011) as well as Lekhanya (2016) indicated that the tenure and size of the SMEs are demographic variables that might affect financial record-keeping. The geographical location and size of SMEs explain the life span, survival and duration of the venture (Lekhanya 2016). Statistics South Africa (2019) further noted that there is a direct relationship between the educational level of SME management and financial record-keeping. Hence, mixed empirical results have been reported which provide support for the contention that location, SME size, and educational attainment might have a significant influence on the financial record-keeping of SMEs. Moreover, financial performance and financial record-keeping appears to be used interchangeably thereby providing partial support to the hypothesis put forward by Momanya and Munene (2013) which stated that demographic variables influence the financial performance of SMEs and that financial recordkeeping is an aspect relating to financial performance. Another lacuna that came to the fore is the lack of inferential statistical analysis in empirical studies conducted (see, e.g. Momanyi \& Munene 2013; Vallabh \& Mhlanga 2015). Descriptive statistics provide an indication of the status of a construct in the sample. However, findings cannot be generalised to the population indicative of a gap in the body of knowledge relating to the informal sector as population.
Therefore, it is hypothesised that demographic variables influence financial record-keeping practices amongst South African SME owners. In light of the above, the primary research objective of the study is to investigate the influence of selective demographic variables on financial recordkeeping in the informal sector, underscoring SMEs.

\section{Contextualisation of the study and literature review}

According to Fourie (2014), the informal sector can be defined as a shadow or grey economy that is not recognised as normal income sources. Essop and Yu (2010) opine that the informal sector includes private unincorporated enterprises (excluding quasi corporations), which produce at least some of the goods or services for sale or barter, have fewer than five paid employees who are not tax registered, and are engaged in non-agricultural activities including professional or technical undertakings. Jayeolo et al. (2020) noted that the informal sector includes micro- or small enterprises that originated as personal or family self-employed commerce focusing on production, processing and cross-country trading. Lebouc, Jaunky and Ramesh (2019) further explained that the informal sector consists of any paid activity that is not acknowledged to government for tax, social security and labour law deductions. The benefits associated with the informal sector subsume affording livelihoods, employment and income for approximately 2.5 million employees and SME owners within the South African context. More specifically, one in every six employed South Africans is working in the informal sector (Fourie 2014). Essop and Yu (2010) reported that threequarters of approximately 1.2 million home-based employees are in informal employment. Fourie (2014) emphasised further that the informal sector provides approximately 850000 paid employment opportunities, which can be extrapolated to almost twice the direct employment in the mining sector. According to Statistics South Africa (2020), the informal sector accounted for 5.2\% of GDP in 2015 and employed 2.65 million employees, representing 17\% of total employment in 2016. Nearly $80 \%$ of those employed in the informal sector have less than grade 12, with beneficiaries consisting of youth, black and female recipients (Essop \& Yu 2010).

Scholars are of the opinion that financial record-keeping is the foundation upon which contemporary SMEs flourish (Ademola, James \& Olore 2012). Dawuda and Azeko (2015) reported that SMEs are dependent on financial records kept in the different ledgers showing transactions such as sales, purchases, income and payments by an individual or organisations. Small- and medium-sized enterprises keep financial records in order to perform coherently, efficiently, effectively and to ensure profitability (Ozatambgo 2009, 2017; Trivedi 2010). Additionally, financial recordkeeping enables SMEs to plan appropriately and detect misappropriation of resources (Mwebesa et al. 2018). Adequate financial record-keeping informs managerial decision-making related to marketing, personnel, credit, pricing, inventory and product development (Muchira 2012; 
Onaolapo \& Adegbite 2014). The main financial records kept by SMEs include statement of profit and loss, statement of financial position or balance sheet, and the statement of cash-flow (Ssekajugo, Tuyishime \& Kasenene 2013), as well as the financial internal control system records that determine the accuracy of company transactions (Ssekajugo et al. 2013). Ademola et al. (2012) noted that poor records can lead to financial inefficiency, resulting in poor organisational performance. Numerous researchers have pointed out that financial record-keeping and financial transparency are inseparable (see, e.g. Ademola et al. 2012; Amoako 2013). Alwardat (2019) reported a positive correlation between financial record-keeping, disclosure quality and investors' perception of financial reporting.

According to the corpus of knowledge, demographic variables, such as gender, age, location and population size, influence SMEs' financial record-keeping practices (see, e.g. Fatoki \& Asah 2011; Lekhamya 2016; Shava \& Rungani 2016). Ascribed to South Africa's history of racial segregation, Makina et al. (2015) opine that race is expected to play a pivotal role in SMEs financial record-keeping presumably as financial recordkeeping is related to financial performance (Momanyi \& Munene 2013). Moreover, the International Finance Corporation (2018) showed that race and gender are determinants and drivers of inequality in SMEs. As such, gender is regarded to have a significant influence on business performance (Makina et al. 2015; Robb \& Watson 2012) and is a discouraging factor for credit demand (Brooksbank et al. 2007; Garwe \& Fatoki 2012). Various authors (see Garwe \& Fatoki 2012; Roper \& Scott 2009) described gender as a factor in the demand and availability of credit. Benedict (2012) reported that $56.8 \%$ male respondents were involved in financial record-keeping, in comparison to $43.2 \%$ female respondents. Additionally, Benedict (2012) further showed that $80 \%$ of respondents involved in the accounting record-keeping of SMEs in the Free State Province, specifically QwaQwa, were 30 years of age. Furthermore, approximately $60 \%$ of respondents in the same research reported on had secondary education (i.e. grade 12), enabling the sample to have the basic skills necessary to record accounting transactions. Likewise, location is an important demographic determinant of financial record-keeping. Chin (2020) opines that SMEs' locations determine the selling rate of business ventures, for example, SMEs in urban areas will be priced differently than the same in rural areas. Location is also related to tenure and size of SMEs, which have a significant influence on financial record-keeping. Fatoki and Asah (2011) indicated that location, tenure and size of SMEs had a positive relationship with access to credit. Elaborating on the foretasted Lekhanya (2016) noted that geographical location and size of SMEs explain the life span, survival and duration of the venture which theoretically influence the financial performance with financial record-keeping part and parcel of said performance (Momanyi \& Munene 2013).

\section{Research design}

A quantitative research design was utilised in the study under discussion. Goertzen (2017) defines quantitative research as a process of analysing data in a numerical format in order to build accurate and reliable measurements that allow for statistical analysis. The quantitative data analysis for this article reflected a selection of findings from the Survey of Employers and the Self-Employed (SESE), which was conducted by Statistics South Africa in the third quarter of 2017 embargoed until March 2019.

The SESE is a national household-based survey implemented to provide comprehensive evidence-based information relating to the characteristics of SMEs in the South African informal sector. Moreover, it endeavours to collect reliable data emphasising ownership and financial management of SMEs which are not registered for Value Added Tax (Statistics South Africa 2019). The SESE was established in 2001 and implemented longitudinally with a 3-year time laps. The content of the survey under discussion included 83 questions that covered nine aspects such as business, operations, general, costs, expenditure, capital, transport, business registration and financial inclusion. Additionally, a section was incorporated to gather demographic information from the respondents on gender, age, educational level, location to mention a few (Statistics South Africa 2019). Variables tested are in the demographic section of the questionnaire found in the metadata located online.

\section{Research approach and methods}

The research reported was based on secondary data retrieved from the Statistics South Africa portal; thus the specific research technique is deemed a secondary data analysis. Secondary data analysis in essence refers to the analysis of data that was collected by a reputable party for an alternative primary purpose (Johnston 2014). Moreover, secondary data analysis is a systematic method with procedural and evaluative steps including hypothesis development, identification of the data set and evaluation thereof (Johnston 2014). Retrieving secondary data from a reliable electronic platform such as Statistics South Africa require studying the data set particulars (i.e. Meta data) which includes the measuring instrument, statistical release, existing output and access conditions underscoring specifically a case by variable data matrix indicative of evaluation procedure. Data management entails cleaning the spreadsheet excluding variables outside the scope of the study. After data cleaning the spreadsheet was imported into the Statistical Package for Social Sciences (SPSS) version 26.

\section{Research participants}

The final sample from the SESE comprises a total number of 1658 respondents covering the nine provinces within South Africa. Thus, there were 1658 respondents in the SESE data set. More specifically, 22\% $(n=364)$ of the sample came from Limpopo, followed by $19.4 \%(n=322)$ from Gauteng, $14.1 \%$ $(n=233)$ from Mpumalanga, $13.6 \%$ representing 225 respondents from KwaZulu-Natal, $11.6 \%(n=192)$ from the Eastern Cape, $7.1 \%(n=117)$ from the Free State, $6.3 \%(n=105)$ from the North West Province, $4.9 \%(n=82)$ from the Western 
Cape and 1\%, representing 18 respondents, from the Northern Cape. In terms of gender distribution, the sample was nearly equally divided. As such, $50.5 \%$ of the sample, representing 844 respondents, indicated the gender categorisation as male, whilst $49.1 \%$, representing 814 respondents, were female. When considering the age distribution, the majority of the sample were between the ages of 40 and 49 years $(n=457$; $27.6 \%)$, followed by respondents between the age of 30 and 39 years $(n=427 ; 25.8 \%)$, those between 50 and 59 years $(n=387$; $23.3 \%)$, followed by respondents between 20 and 29 years $(n=220 ; 13.3 \%)$. The respondents who were 60 years and older represented $9.5 \%$ of the sample $(n=159)$ and the respondents younger than 20 years of age represented only $0.5 \%(n=8)$ of the sample. With reference to population grouping, the overwhelming majority of the sample, that is, $92.9 \%$, representing 1541 respondents, indicated the racial categorisation as African and/or black. The remainder of the sample comprised 3.1\% $(n=52)$ white people, $2.7 \%(n=44)$ mixed race and $1.3 \%(n=21)$ Indian and/or Asian respondents. In terms of the marital status of respondents, 38.5\% $(n=638)$ of the sampled noted that they were married, whilst $34.8 \%$ ( $n=577)$ indicated that they have never been married. Pursuantly, $12.8 \%$, representing 213 respondents, indicated they were cohabiting, whilst $10 \%(n=165)$ noted they were either a widow or widower. Finally, 65 respondents, representing $3.9 \%$ of the sample, were either divorced or separated.

When reporting on educational qualification, it should be noted that the dataset was recoded to include the following categories, namely secondary formal schooling $(n=1374$; $82.9 \%)$, technical qualification $(n=13 ; 0.8 \%)$, diploma or degree $(n=125 ; 7.5 \%)$, honours degree $(n=4 ; 0.2 \%)$, and postgraduate qualification $(n=7 ; 0.4 \%)$. Nonetheless, $8.1 \%$ of the sample, representing 135 respondents indicated that their educational qualification could not be classified in the given categories. Moreover, in terms of business typology (i.e. SME size), two categories emerged. These include microenterprises with an annual turnover between R0.00 and R199 000, representing 99.7\% $(n=1653)$ of the sample, and small enterprises $(n=5 ; 0.3 \%)$, with an annual turnover between R200 000 and R500 000.

To arrive at the sample mentioned above, Statistics South Africa employed a two-pronged sampling strategy to gather data. Firstly, in the absence of a standardised sampling frame purposive sampling was utilised to identify respondents in accordance with the Quarterly Labour Force Survey (QLFS) administered in the third quarter. Etikan, Musa and Alkassim (2016) noted that purposive sampling, albeit a nonprobability sampling approach, is used when the population is unknown concentrating on respondents with particular predetermined characteristics best able to meaningfully contribute to the research under study. More specifically, a maximum variation sampling strategy was followed also known as heterogeneous sampling, selecting respondents across a broad spectrum relating to the study topic. To this end, diverse sectors was included in the SESE sample, namely trade $(51.5 \%)$, community and social services (12.2\%), construction $(12 \%)$, finance $(7.9 \%)$, manufacturing $(7.3 \%)$, transport (5.8\%) and agriculture (1.6\%). Data collection took place from July 2017 to September 2017 by trained enumerators in the SESE sector (Statistics South Africa 2019).

\section{Statistical analysis}

The SPSS version 26 was utilised to perform descriptive and inferential analyses. Descriptive statistics were computed to provide a profile of the sample. Inferentially, binomial logistic regression was performed to investigate the research hypotheses. Binomial, also referred to as binary logistic regression, predicts categorical outcomes with dichotomous dependent variables. Statistically, logistic regression predicts probability. Therefore, for each data point, there is a vector of features $\chi_{1}$ and an observed class $Y_{1}$. The probability is $p$, if $Y_{1}=1$ or $(1-p)$ if $Y_{1}=0$ (Epaphra \& Kiwia 2021). The likelihood function for logistic regression is expressed as: $\mathrm{L}$ $\left(\beta_{0-} \beta_{7}\right)=\pi^{\mathrm{n}}{ }_{\mathrm{i}=1} \mathrm{p}\left(\chi_{1}\right)^{\mathrm{yi}}\left(1-\mathrm{p}\left[\mathrm{Y}_{1}\right]\right)^{1-\mathrm{Y}}$. The log-likelihood function is: $\log (L)=\sum_{i=1}^{\mathrm{n}} \mathrm{Y}_{1} \log \mathrm{p}\left(\chi_{1}\right)+\left(1-\mathrm{Y}_{1}\right) \log \left(1-\mathrm{p}\left[\chi_{1}\right]\right)$ according to Epaphra and Kiwia (2021).

The research hypotheses stated that:

$\mathbf{H}_{1}$ : Demographic variables, that is, province, gender, age, educational level, marital status, population group and business typology statistically and significantly influence financial record-keeping practices for SMEs.

Statistical significance was set at either the 99th $(p \leq 0.01)$ or 95th $(p \leq 0.05)$ percentile.

\section{Ethical considerations}

Secondary coded data was utilised in the research, with no interaction with human or animal participants. However, ethical clearance was obtained from the EMS-REC of the North-West University.

\section{Results}

The primary aim of the study was to investigate the influence of demographic variables on the financial record-keeping practices in the South African informal business sector. To contextualise the results, Table 1 illustrates findings from the descriptive analysis. As deduced from Table 1 overleaf, the overwhelming majority of the sample, representing $79.4 \%$ or 1317 respondents, fail to keep any financial records. Moreover, $9.7 \%(n=161)$ of the sample kept informal records of sales and/or expenditures and 5.9\% $(n=97)$ kept some record. Only 5\% $(n=83)$ of the sample kept full annual financial accounts. From those respondents who identified some form of financial record-keeping practice, 51\% $(n=174)$ indicated that financial accounts are kept separate from general household accounts; whilst, $24.4 \%(n=83)$ of the sample indicated that not all financial record-keeping is separated and $24.6 \%(n=84)$ indicated that no separation is present. Relating to the rationale for not keeping financial records, 
TABLE 1: Descriptive statistical results emphasising financial record-keeping practices.

\begin{tabular}{|c|c|c|c|c|}
\hline Variable & Level of the variable & $N$ & $\%$ & $\underset{\%}{\text { Cumulative }}$ \\
\hline \multirow[t]{4}{*}{$\begin{array}{l}\text { Financial record- } \\
\text { keeping practice }\end{array}$} & $\begin{array}{l}\text { Simple informal records of } \\
\text { sales and/or expenditures }\end{array}$ & 161 & 9.7 & 9.7 \\
\hline & $\begin{array}{l}\text { Some accounts but not } \\
\text { complete (e.g. expenditures) }\end{array}$ & 97 & 5.9 & 15.6 \\
\hline & Full annual accounts & 83 & 5.0 & 20.6 \\
\hline & No accounts kept & 1317 & 79.4 & 100.0 \\
\hline \multirow[t]{3}{*}{$\begin{array}{l}\text { Separate account } \\
\text { kept }\end{array}$} & $\begin{array}{l}\text { Yes, all accounts are recorded } \\
\text { separately }\end{array}$ & 174 & 51.0 & 51.0 \\
\hline & $\begin{array}{l}\text { Some are recorded separately, } \\
\text { other accounts together }\end{array}$ & 83 & 24.4 & 75.4 \\
\hline & $\begin{array}{l}\text { No, all accounts are recorded } \\
\text { together }\end{array}$ & 84 & 24.6 & 100.0 \\
\hline \multirow{4}{*}{$\begin{array}{l}\text { Rationale for not } \\
\text { keeping financial } \\
\text { records }\end{array}$} & A lack of skills & 89 & 6.8 & 6.8 \\
\hline & The SME is too small & 532 & 40.9 & 47.7 \\
\hline & No time to keep records & 69 & 5.3 & 53 \\
\hline & $\begin{array}{l}\text { Do not see a need to keep } \\
\text { records }\end{array}$ & 612 & 47 & 100 \\
\hline
\end{tabular}

SME, Small and medium-sized enterprises.

$47 \%(n=612)$ of the sample did not perceive the need to keep financial records, followed by $40.9 \%(n=532)$ who indicated that the enterprise is too small, $6.8 \%(n=89)$ of the sample identified a lack of skills, and 5.3\%, representing 69 respondents, referred to a lack of time.

To test the research hypotheses, binary logistic regression modelling was conducted, with the results displayed in Table 2.

Binary logistic regression was performed to determine the influence of a selected demographic variable on the likelihood of participating in financial record-keeping practices. The model contained seven independent variables such as province, gender, age, population group, marital status, education and business typology. The model incorporating all predictor variables was statistically significant $\left(\right.$ chi-square $=165.995 ; \mathrm{DF}=27 ; p \leq 0.000^{* *}$ ), indicative of the ability to distinguish between respondents engaging in financial record-keeping and the alternative. The model in totality explained between 9.5\% (Cox and Snell $R$ square) and $14.9 \%$ (Nagelkerke $\mathrm{R}$ square) of the variance in financial record-keeping practice, and correctly classified $81.1 \%$ of cases. As evident in Table 2, four of the independent variables had a statistically significant influence on the dependent variable. More specifically, province, population group and education, respectively, had a statistically significant influence on the 99th percentile; whilst, marital status reported a statistically significant impact on the 95th percentile. Furthermore, Mpumalanga statistically significantly differs from the reference group, that is, the Western Cape on the 95th percentile. Mixed race respondents statistically significantly differ from black respondents on the 95th percentile, whilst white respondents differed on the 99th percentile. In terms of marital status, widower or widow respondents statistically significantly differ from married respondents on the 99th percentile with reference to financial record-keeping practice. Lastly, the respondents with a diploma statistically significantly differ
TABLE 2: Estimates from the logistic regression model relating to financial record-keeping.

\begin{tabular}{|c|c|c|c|c|c|c|c|}
\hline \multirow[t]{2}{*}{ Variable } & \multirow[t]{2}{*}{$\boldsymbol{B}$} & \multirow[t]{2}{*}{ SE } & \multirow[t]{2}{*}{$z$} & \multirow[t]{2}{*}{ DF } & \multirow[t]{2}{*}{$p$} & \multicolumn{2}{|c|}{$95 \% \mathrm{Cl}$} \\
\hline & & & & & & Lower & Upper \\
\hline Province (ref. WC) & - & - & 36.746 & 8 & $0.000 * *$ & - & - \\
\hline Province(EC) & 0.014 & 0.353 & 0.002 & 1 & 0.969 & 0.508 & 2.025 \\
\hline Province(NC) & -0.574 & 0.604 & 0.900 & 1 & 0.343 & 0.172 & 1.843 \\
\hline Province(FS) & -0.334 & 0.379 & 0.777 & 1 & 0.378 & 0.341 & 1.505 \\
\hline Province(KZN) & 0.229 & 0.372 & 0.378 & 1 & 0.539 & 0.606 & 2.608 \\
\hline Province(NW) & -0.480 & 0.384 & 1.557 & 1 & 0.212 & 0.291 & 1.315 \\
\hline Province(GP) & 0.297 & 0.344 & 0.747 & 1 & 0.387 & 0.686 & 2.641 \\
\hline Province(MP) & -0.751 & 0.345 & 4.747 & 1 & $0.029 *$ & 0.240 & 0.927 \\
\hline Province(LP) & 0.231 & 0.342 & 0.457 & 1 & 0.499 & 0.645 & 2.463 \\
\hline Female (ref. male) & 0.040 & 0.133 & 0.090 & 1 & 0.764 & 0.801 & 1.352 \\
\hline $\begin{array}{l}\text { Age (ref. } 20 \text { years } \\
\text { and below) }\end{array}$ & - & - & 1.260 & 5 & 0.939 & & - \\
\hline $20-29$ & -19.782 & 14021.829 & 0.000 & 1 & 0.999 & 0.000 & - \\
\hline $30-39$ & -19.916 & 14021.829 & 0.000 & 1 & 0.999 & 0.000 & - \\
\hline $40-49$ & -19.901 & 14021.829 & 0.000 & 1 & 0.999 & 0.000 & - \\
\hline $50-59$ & -19.888 & 14021.829 & 0.000 & 1 & 0.999 & 0.000 & - \\
\hline 60 and older & -19.650 & 14021.829 & 0.000 & 1 & 0.999 & 0.000 & - \\
\hline $\begin{array}{l}\text { Population group } \\
\text { (ref. black) }\end{array}$ & - & - & 29.472 & 3 & $0.000 * *$ & - & - \\
\hline Mixed race & -0.919 & 0.372 & 6.115 & 1 & $0.013^{*}$ & 0.193 & 0.826 \\
\hline Indian/Asian & -0.198 & 0.589 & 0.113 & 1 & 0.737 & 0.259 & 2.603 \\
\hline White & -1.874 & 0.367 & 26.135 & 1 & $0.000 * *$ & 0.075 & 0.315 \\
\hline $\begin{array}{l}\text { Marital status } \\
\text { (ref. married) }\end{array}$ & - & - & 11.738 & 4 & $0.019 *$ & - & - \\
\hline Co-habiting & 0.443 & 0.231 & 3.683 & 1 & 0.055 & 0.991 & 2.446 \\
\hline Widow/widower & 0.851 & 0.289 & 8.681 & 1 & $0.003 * *$ & 1.330 & 4.126 \\
\hline $\begin{array}{l}\text { Divorced/ } \\
\text { Separated }\end{array}$ & 0.074 & 0.319 & 0.054 & 1 & 0.817 & 0.576 & 2.014 \\
\hline Never married & 0.261 & 0.159 & 2.694 & 1 & 0.101 & 0.951 & 1.771 \\
\hline $\begin{array}{l}\text { Education (ref. } \\
\text { secondary } \\
\text { schooling) }\end{array}$ & - & - & 20.835 & 5 & $0.001 * *$ & - & - \\
\hline $\begin{array}{l}\text { Technical } \\
\text { qualification }\end{array}$ & -0.279 & 0.684 & 0.166 & 1 & 0.684 & 0.198 & 2.895 \\
\hline Diploma/degree & -0.922 & 0.217 & 18.039 & 1 & $0.000 * *$ & 0.260 & 0.609 \\
\hline $\begin{array}{l}\text { Honours } \\
\text { qualification }\end{array}$ & -1.460 & 1.264 & 1.332 & 1 & 0.248 & 0.019 & 2.770 \\
\hline Postgraduate & -22.000 & 13725.231 & 0.000 & 1 & 0.999 & 0.000 & - \\
\hline Other & 0.288 & 0.284 & 1.022 & 1 & 0.312 & 0.763 & 2.329 \\
\hline $\begin{array}{l}\text { Small (ref. micro } \\
\text { enterprise) }\end{array}$ & -2.151 & 1.226 & 3.079 & 1 & 0.079 & 0.011 & 1.286 \\
\hline Constant & 21.253 & 14021.829 & 0.000 & 1 & 0.999 & - & - \\
\hline $\begin{array}{l}Y=1 \text { (no financial } \\
\text { records) }\end{array}$ & 1.351 & 0.061 & 494.554 & 1 & $0.000 * *$ & - & - \\
\hline $\begin{array}{l}\text { Log pseudo- } \\
\text { likelihood }\end{array}$ & 1519.071 & - & - & - & - & - & - \\
\hline Cases analysed & & 658 & Missing $c$ & cases & & 0 & \\
\hline
\end{tabular}

WC, Western Cape; EC, Eastern Cape; FS, Free State; KZN, KwaZulu Natal; NW, North-West; GP, Gauteng; MP, Mpumalanga; LP, Limpopo; DF, Degrees of Freedom

$*, p \leq 0.05 ; * *, p \leq 0.01$.

from the respondents with a secondary education on the 99th percentile.

\section{Discussion of findings}

According to the results elucidated, the overwhelming majority of the sample, representing $79.4 \%$, battled with financial record-keeping. Research conducted by Myeko and Madikane (2019) confirms the results presented with specific reference to South African SME proprietors forsaking financial record-keeping in operations. The main justifications that came to the fore include lack of insight into the important role of financial record-keeping skills as well as time 
management. The findings presented are supported by Muteti, Namusonge and Nzomo (2018) as well as Myeko and Madina (2019), who reported that informal sectors are confronted with a lack of knowledge on record-keeping in business ventures. Muteti et al. (2018), supported by Myeko and Madina (2019), further indicated that SMEs in the informal sector lack time to take care of their business records ascribed to focusing on their primary business goal such as selling products. The afore-stated can also be because of the lack of understanding relating to the rationale for financial record-keeping. Myeko and Madina (2019) further accentuate that SMEs in the informal sector lack knowledge or understanding as to the link between business performance and financial record-keeping. Furthermore, Olukotun, James and Olore (2012) indicated that many SMEs experience a lack of knowledge, skills, and time, and some avoid cost associated to financial record-keeping in their business ventures. More specifically, Myeko and Madina (2019) revealed that $44.4 \%$ of SMEs in the Engcobo informal sector lack the basic skills to keep financial records, and $31.1 \%$ said that they do not have to maintain financial records in their SME.

Findings from the binary logistic regression modelling revealed that province, population group, education and marital status statistically significantly influence financial record-keeping practices. The finding related to province was corroborated by Essop and Yu (2010), who reported that metro areas such as Gauteng, KwaZulu-Natal and the Eastern Cape emphasise financial record-keeping in comparison to nonmetro areas such as Limpopo and the North West Province. In terms of age as demographic predictor, the findings presented refuted Musah (2017), who indicated that in Ghana, the age of SME owners predominantly ranged between 35 and 44 years of age, indicative of a hypothesised influence of age as demographic predictor. In terms of population group, Makina et al. (2015) opine that race is expected to play a pivotal role in SMEs' financial record-keeping, which was confirmed in the current study. Moreover, the International Finance Corporation (2018) also showed that race is a determinant and driver of inequality in SMEs. With reference to education, Dawuda and Azeko (2015) showed that the majority of retail clothing industries in South Africa are owned by diploma holders, indicative of a possible demographic driver which was confirmed in the current study. Therefore, SMEs in the informal sector had basic skills for financial record-keeping such as the ability to read and write and most likely arithmetic skills (i.e. addition, subtraction, multiplication and division), viz. the basic skills required for financial record-keeping. The findings presented corroborate those by Momanyi and Munene (2013), who noted that the respondents had acquired basic level of education.

Gender did not yield a statistically significant result, thus refuting the majority of empirical literature. For example, the International Finance Corporation (2018) indicated gender as a determinant of inequality in SMEs. Gender is also known as a determinant factor for business growth (Kobeissi 2010). Global Entrepreneurship Monitor (GEM 2016) as well as Myeko and Madina (2019) revealed that there is a wider gender gap between males and females within the South African context. For instance, there are only six (6) females to every 10 males engaged in early-stage small business activities. This gender gap varies according to business typology operated in a given country. For example, in Cameroon, females had higher SME engagement than their male counterparts in Kumba Municipality (Negou 2018). However, gender did not statistically significantly influence financial record-keeping in the current study.

Based on the results presented, the first research hypothesis was partially accepted. Thus, province, population group, educational attainment and marital status statistically significantly influenced financial record-keeping.

\section{Practical implications}

Three main contributing factors for the perceived absence of financial record-keeping practice in small- and medium-sized entities in the informal sector subsume poor time management, lack of skills and knowledge, with specific reference to the pivotal role thereof. In accordance with the modernisation theory, policy development, for example, public sector policies based on the efficiency principle should promote growth in the informal sector by means of economic enablement to obtain seed funding thereby stimulating advanced stages of economic development. Moreover, industries and sectors part and parcel of corporate responsibility or community engagement could sponsor interventions for designated demographic groups addressing the mentioned factors in order to effectively implement financial record-keeping in the informal sector. Interventions could include time management workshops, information sessions on the importance of financial record-keeping, basic financial record-keeping workshops and mentoring. Informal sectors should ensure that the period and time to which their financial records are to be kept are outlined. This would enhance adequate reporting and records in SMEs. Interventions should also target specific provinces, population groups, educational levels and marital status groups (see Table 2).

\section{Limitations and recommendations}

The following acknowledged caveats should be considered when interpreting results. Statistical analysis was based on the data generated by Statistics South Africa and subsequently subject to suppositions contained in the statistical release (P0276). The accuracy of the results is premised on the same with reference to the measuring instrument with limited available information. The results are premised on the assumption that SME owners in the informal sector did not outsource their financial record-keeping. Lastly, the utilisation of nonprobability sampling influenced the external validity of results, resulting in restraint when generalising results to the population. Consequently, caution is advised when interpreting results. Future research endeavours could focus on the development and piloting of a measuring instrument with continuous variables. 


\section{Conclusion}

The contribution of the informal sector to economic growth has recently gained momentum. Thus, SMEs can be considered as a fundamental part of every nation's economic activity. Financial record-keeping has been identified as keystone to the success of SMEs, with disregard to produce adequate financial records resulting in economic failure. Against this background, the study showed that the majority of informal sector SMEs did not keep financial records ascribed to inadequate skills and knowledge on the significance of financial record-keeping. The demographic variables such as province, population group and highest academic qualification statistically significantly influenced financial record-keeping practices the most. Whilst, marital status influenced financial record-keeping to a lesser extent howbeit still statistically significantly. Specifically, the respondents in Mpumalanga province differed statistically significantly from the respondents in the Western Cape. Mixed race and White respondents differed statistically significantly from Black respondents in terms of financial record-keeping. The respondents with either a degree or diploma statistically significantly differed from respondents with a secondary school qualification. Whilst respondents who lost a spouse statistically significantly differed from married respondents. A possible reason might be time constraints of married respondents. The evidence generated by the research presented could be utilised by policymakers when debating about developing or expanding the informal sector, focusing specifically on targeted race groups, provinces (i.e. Mpumalanga) and educational groups (i.e. secondary school graduates).

\section{Acknowledgements}

The authors would like to acknowledge the GIFT research entity at the North-West University for providing invaluable support to conduct this research.

\section{Competing interests}

The authors declare that no financial or personal relationship(s) have inappropriately influenced the writing of this manuscript.

\section{Authors' contributions}

P.J. conceptualised the article and was responsible for statistical analyses as well as co-authoring the manuscript. L.N. co-authored the literature and made conceptual contributions.

\section{Funding information}

The research under discussion did not receive any financial support from any funding agency in the public, commercial or not-for-profit sectors.

\section{Data availability}

Data sharing is applicable and as such can be downloaded from the Statistics South Africa portal.

\section{Disclaimer}

The views expressed in the submitted article are those of the authors and not an official position of the institution or funder.

\section{Reference}

Ademola, G.O., James, S.O. \& Olore, I., 2012, 'The roles of record keeping in the survival and growth of small scale enterprises in ljumu Local Government Area of Kogi State', Global Journal of Management and Business Research 12(13), 55-66.

Alwardat, A., 2019, 'Disclosure quality and its impact on financial reporting quality, audit quality and Investors' perceptions of the quality of financial reporting: A literature review', Accounting and Finance Research 8(3), 201-218. https://doi. org/10.5430/afr.v8n3p201

Amoako, G., 2013, 'Accounting practices of SMEs: A case study of Kumasi Metropolis in Ghana', International Journal of Business and Management 8(24), 121-139. https://doi.org/10.5539/ijbm.v8n24p73

Anokyewaa, C., 2015, 'Computerized recordkeeping amongst small and medium enterprises: A case study in Sunyani municipality', Unpublished MBA thesis, University of Science and Technology, Kumasi.

Barbara, R., 2010, 'Record management, change management, service systems', Management Journal 20(1), 124-137. https://doi.org/10.1108/09565691011039898

Benedict, R.G., 2012, 'An investigation of the accounting records maintained by black businesses in QWAQWA', Unpublished Master thesis, University of Johannesburg, Johannesburg.

Boame, I., Solace, K. \& Issaka, S., 2014, 'Adoption of accounting practices and its effects on SMESs: Financial perspective of sachet water producers in Northern', Research Journal of Finance and Accounting 5(17), 166-179.

Brink, A., Cant, M.C. \& Ligthelm, A., 2003, 'Problems experienced by small businesses in South Africa', in proceedings of the 16th Annual conference of Small Enterprise Association of Australia and New Zealand, Ballarat, Australia, 28th September to 01 October 2003.

Brooksbank, D.J., Jones-Evans, D., Kwong, C.C.Y. \& Thompson, P., 2007, 'Are potential female entrepreneurs in the UK financially constrained?', paper presented at the International Council for Small Business (ICSB) 52nd World Congress, June 12-15, Turku, Finland.

Chelimo, J.K. \& Sopia, I.O., 2014, 'Effects of bookkeeping on growth of small and medium business enterprises in Kabarnet Town, Baringo County, Kenya', International Journal of Science and Research 3(12), 432-437.

Chin, J.T., 2020, 'Location choice of new business establishments: Understanding the local context and neighborhood conditions in the United States', Sustainability 12(2), 1-17. https://doi.org/10.3390/su12020501

Dawuda, A. \& Azeko, I., 2015, 'An assessment of financial records keeping behaviour of small scale businesses in Ghana: A case study of Bolgatanga Municipality', International Journal of Finance and Accounting 4(3), 187-194.

Epaphra, M. \& Kiwia, B.P., 2021, 'Financial literacy and participation in the financial markets in Tanzania: An application of the logit regression model', Journal of Economic and Financial Sciences 14(1), a545. https://doi.org/10.4102/jef.v14i1.545

Essop, H. \& Yu, D., 2008, The South African informal sector (1997-2006), Stellenbosch Economic Working Papers, 03 August 2008, Stellenbosch University, Department of Economics.

Etikan, I., Musa, S.A. \& Alkassim, R.S., 2016, 'Comparison of convenience sampling and purposive sampling', American Journal of Theoretical and Applied Statistics 5(1), 1-4. https://doi.org/10.11648/j.ajtas.20160501.11

Fatoki, O. \& Asah, F., 2011, 'The impact of firm and entrepreneurial characteristics on access to Debt Finance by SMEs in King Williams' Town, South Africa', Internationa access to Debt Finance of Business and Management 6(8), 170-179. https://doi.org/10.5539/
Journal ijbm.v6n8p170

Fourie, F., 2018, Analysing the informal sector in South Africa: Knowledge and policy gaps, conceptual and data challenges. The South African informal sector: Creating jobs, reducing poverty, HSRC Press, Cape Town.

Fred, N.U., 2003, 'Survey of small and medium-scale industries and their potential in Nigeria', in Small and medium industries equity investments scheme (SMIEIS), pp. 6-18, CBN Training Centre, Lagos.

Garwe, D.K. \& Fatoki, O., 2012, 'The impact of gender on SME characteristics and access to debt finance in South Africa', Development Southern Africa 29(3), 448-461. https://doi.org/10.1080/0376835X.2012.706040

Global entrepreneurship monitor (GEM), 2019, Is South Africa heading for an economic meltdown?, University of Cape Town, Development Unit for New Enterprises, viewed 15 October 2021, from https://www.gemconsortium.org/report.

Goertzen, M.J., 2017, 'Introduction to quantitative research and data', Library Technology Reports 53(4), 12-18.

Huang, G., Xue, D. \& Wang, B., 2020, 'Integrating theories on informal economies: An examination of causes of urban informal economies in China', Journal of Sustainability 12(2), 2738-2752. https://doi.org/10.3390/su12072738

Hussein, M.S. \& Kühl, R., 2014, 'Performance of micro and small-scale enterprises (MSEs) in Tanzania: Growth hazards of fruit and vegetables processing vendors', Journal of Applied Economics and Business Research 4(2), 120-133.

International Finance Corporation, 2018, The unseen sector a report on the MSME opportunity in South Africa, International Finance Corporation, Washington, DC. 
Jayeolo, O., Sidek, S., Owoeye, I. \& Kazeem, Y.K., 2020, 'Gender and the performance of informal sector enterprises', European Scientific Journal 16(4), 57-73. https:// of informal sector enterprises', Europ
doi.org/10.19044/esj.2020.v16n4p57

Johnston, M.P., 2014, 'Secondary data analysis: A method of which the time has come', Qualitative and Quantitative Methods in Libraries 3, 619-626.

Karagiorgos, A., Gaitanaki, A., Ignatiou, O. \&Terzidou, A., 2020, 'Role and contribution of administrative accounting to small and very small businesses', Journal of Accounting and Taxation 12(2), 75-84. https://doi.org/10.5897/JAT2020.0399

Kobeissi, N., 2010, 'Gender factors and female entrepreneurship: International evidence and policy implications', Journal of International entrepreneurship 8 , 1-35. https://doi.org/10.1007/s10843-010-0045-y

Lebouc, M., Jaunky, V.C. \& Ramesh, V., 2019, 'Tourism and the informal sector', International Journal of Management and Research 3(3), 67-76.

Lekhanya, L.P., 2016, 'Determinants of survival and growth of small and medium enterprises in rural KwaZulu-Natal', Unpublished Doctoral Dissertation, University of Western Cape, Cape Town.

Makina, D., Beyene, A., Kingstone, F., Khumalob, M.J. \& Maposa, O., 2015, Financial access and SME size in South Africa, Fin-Mark Trust, Johannesburg.

Mohamed, W., Yasseen, Y. \& Nkhi, N., 2020, 'International financial reporting standards for small and medium-sized entities: A survey showing insights of South African accounting practitioners', Journal of Economic and Financial Sciences 13(1), a489. https://doi.org/10.4102/jef.v13i1.489

Momanyi, M.E. \& Munene, C., 2013, 'Factors affecting financial performance of youth owned enterprises Kenya: A case of youth owned enterprises in Kisii Town', Interdisciplinary Journal of Contemporary Research in Business 5(6), 542-559.

Muchira, B.W., 2012, 'Record keeping and growth of micro and small enterprises: A case study municipally in Kenya', Unpublished Master's thesis, Kenyatta University, Kenya.

Muhammad, L. \& Isah, A.I., 2018, 'Impact of financial recordkeeping in the growth and survival of small and medium enterprises (SMEs) in Zaria', Katsina Journal of Economics and Development 1(2), 293-301.

Muriithi, S.M., 2017, 'African small and medium (SMEs) contributions, challenges, and solutions', European Journal of Research and Reflections in Management Sciences $5(1), 36-48$

Musah, A., 2017, 'Benefits and challenges of bookkeeping and accounting practices of SMEs and its effect on growth and performance in Ghana', Journal of Accounting, Business and Management 24(2), 16-37.

Muteti, N., Namusonge, M. \& Nzomo, D., 2018, 'Accounting systems for records keeping practices for small enterprise development in Makueni County, Kenya',
Open Journal of Accounting 7(3), 181-190. https://doi.org/10.4236/ojacct. Open Journal

Mwebesa, L.C.K., Kansiime, C., Asiimwe, B.B., Mugambe, P. \& Rwego, I., 2018, 'The effect of financial record keeping on financial performance of development groups in rural areas of Western Uganda', International Journal of Economics and groups in rural areas of Western Uganda', International Journal of
Finance 10(4),136-145. https://doi.org/10.5539/ijef.v10n4p136

Myeko, Z. \& Madikane, V., 2019, 'Challenges of record keeping for Engcobo small, micro and medium businesses, South Africa', Global Journal of Management and Business Research 19(3), 1-9. https://doi.org/10.30845/aijcr.v9n3p2

Negou, E., 2018, 'The role of bookkeeping on the survival of very small businesses in the Kumba Municipality', International Journal of Advanced Engineering, Management and Science 4(2), 713-723. https://doi.org/10.22161/ijaems.4.10.1

Nketsiah, I., 2018, 'Financial record keeping practices of small business operators in the Sokindi-Takoradi Metropolitan Area of Ghana', Asian Journal of Economics, Business and Accounting 6(3), 1-9. https://doi.org/10.9734/AJEBA/ 2018/39291

Nyathi, M. \& Benedict, O.H., 2017, 'An assessment on bookkeeping training and understanding of small-business owners in the retail clothing industry in Cape Town, South Africa', Journal of Economics 8(2), 109-120.

Oduro, A.K., Marfo, O.E., Gyabaah, E.N. \& Oduro, G., 2014, 'Accounting records keeping practices of SME's in Ghana: Evidence from Sunyani Municipality', British Journal of Economics, Finance and Management Science 9(1), 120-132.
Olukotun, A.G., James, S.O. \& Olore, I. 2012, 'The role of record keeping in the survival and growth of small-scale enterprises in IJumu local area of Kogi state', Global Journal of Management and Business Research 12(13), 54-66.

Onaolapo, A. \& Adegbite, I., 2014, 'The analysis of the impact of accounting records keeping on the performance of small scale enterprises', International Journal of Academic Research in Business and Social Sciences 4(1), 1-17.

Owolabi, S.A., Ogundajo, G.O. \& Olayinka, I.M., 2016, 'Bookkeeping and sustainability of small scale businesses in Nigeria: An assessment of Agbara Local Government Area, Ogun State', Unique Journal of Business Management Research 3(1), 11-21.

Ozatambgo, O., 2009, 'Financial Record Keeping in Religious Organizations: A Case Study of Catholic Church in Enugu Diocese. Understanding the context of electronic records management. Training in Electronic records management', Unpublished Master's thesis, University of Nigeria, Enugu Campus.

Ozatambgo, O., 2017, 'Financial record keeping in religious organizations: A case study of Catholic Church in Enugu Diocese', Unpublished Master's dissertation, University of Nigeria, Enugu Campus.

Pretorius, M.M., 2015, 'South African small business taxation registration compliance', Unpublished Master's dissertation, University of South Africa.

Radipere, S. \& Dhliwayo, S., 2014, 'The role of age and business size on small business performance in the South African small enterprise sector', Problems and Perspectives in Management 12(4), 7-12.

Robb, A.M. \& Watson, J., 2012, 'Gender differences in firm performance: Evidence from New ventures in the United States', Journal of Business Venturing 27(5), 544-558. https://doi.org/10.1016/j.jbusvent.2011.10.002

Roper, S. \& Scott, J.M., 2009, 'Perceived financial barriers and the start-up decision: An econometric analysis of gender differences using GEM data', International Small Business Journal 27(2), 149-71. https://doi.org/10.1177/0266242608100488

Rothernberg, A.D., Gaduh, A. \& Burger, N.E., 2016, 'Rethinking Indonesia's informal sector', World Development 80, 96-113. https://doi.org/10.1016/j.worlddev. 2015.11.005

Shava, H. \& Rungani, E.C., 2016, 'Influence of gender on SME performance in emerging economies', Acta Commercii 16(1), a408. https://doi.org/10.4102/ac.v16i1.408

Sibanda, J.J. \& Manda, D.C., 2016, 'Symptoms of accounting practices that contribute to small business failures in South Africa', Problems and Perspectives in Management 14(4), 194-202. https://doi.org/10.21511/ppm.14(4-1).2016.08

Ssekajugo, D., Tuyishime, E. \& Kasenene, E.S., 2013, ‘Performance of Public Institutions in Ngororero District, North Western Rwanda', International Journal of Economics and Finance 10(4), 136-145.

Statistics South Africa, 2019, Survey of employers and the self-employed 2017, Statistical Release No. P0276. Pretoria.

Statistics South Africa, 2020, Improving lives through data ecosystem, viewed 15 October 2021, from http://www.statssa.gov.za/?s=small+business.

Steyn, Z. \& Van Staden, L.J., 2018, 'Investigating selected self-management competencies of managers', Acta Commer 18(1), 1-22. https://doi.org/10.4102/ ac.v18i1.530

Trivedi, S.M., 2010, 'An analysis of financial performance of State Road Transport Corporation in Gujarat', Unpublished Doctoral dissertation, Saurashtra University.

Tshuma, M.C. \& Jari, B., 2013, 'The informal sector as a source of household income: The case of Alice town in the Eastern Cape province of South Africa', Journal of African Studies and Development 5(8), 104-111.

Vallabh, D. \& Mhlanga, O., 2015, 'Influence of demographic factors on business performance in small to medium tourism enterprises (SMTEs)', African Journal of Hospitality, Tourism and Leisure 4(2), 1-9.

Van Heerden, S.W., 2011, 'Street trading in Cape Town CBD: A study of the relationship between local government and street traders', Unpublished doctoral dissertation, Stellenbosch University, Stellenbosch.

Williams, S. \& Schaefer, A., 2013, 'Small and medium sized enterprises and sustainability: Managers' values and engagement with environmental and climate change issues', Business Strategy and the Environment 22(3), 173-186. https:// doi.org/10.1002/bse.1740 